\title{
The role of methane in projections of 21st century stratospheric water vapour
}

\author{
Laura E. Revell ${ }^{1,2}$, Andrea Stenke ${ }^{2}$, Eugene Rozanov ${ }^{2,3}$, William Ball ${ }^{2,3}$, Stefan Lossow ${ }^{4}$, and Thomas Peter ${ }^{2}$ \\ ${ }^{1}$ Bodeker Scientific, Christchurch, New Zealand \\ ${ }^{2}$ Institute for Atmospheric and Climate Science, ETH Zurich, Zurich, Switzerland \\ ${ }^{3}$ Physical-Meteorological Observatory/World Radiation Center, Davos, Switzerland \\ ${ }^{4}$ Karlsruhe Institute of Technology, Karlsruhe, Germany \\ Correspondence to: Laura E. Revell (laura@bodekerscientific.com)
}

Received: 22 June 2016 - Published in Atmos. Chem. Phys. Discuss.: 7 July 2016

Revised: 24 September 2016 - Accepted: 27 September 2016 - Published: 21 October 2016

\begin{abstract}
Stratospheric water vapour (SWV) is an important component of the Earth's atmosphere as it affects both radiative balance and the chemistry of the atmosphere. Key processes driving changes in SWV include dehydration of air masses transiting the cold-point tropopause (CPT) and methane oxidation. We use a chemistry-climate model to simulate changes in SWV through the 21st century following the four canonical representative concentration pathways (RCPs). Furthermore, we quantify the contribution that methane oxidation makes to SWV following each of the RCPs. Although the methane contribution to SWV maximizes in the upper stratosphere, modelled SWV trends are found to be driven predominantly by warming of the CPT rather than by increasing methane oxidation. SWV changes by -5 to $60 \%$ (depending on the location in the atmosphere and emissions scenario) and increases in the lower stratosphere in all RCPs through the 21st century. Because the lower stratosphere is where water vapour radiative forcing maximizes, SWV's influence on surface climate is also expected to increase through the 21 st century.
\end{abstract}

\section{Introduction}

Stratospheric water vapour (SWV) plays an important role in the Earth's radiative balance (Hartmann et al., 2013) such that decreases in SWV concentrations during the 2000s may have slowed surface temperature increases over the same period (Solomon et al., 2010). Increases in SWV lead to stratospheric ozone depletion both by enhancing odd hydrogen cy- cles and by increasing the prevalence of polar stratospheric clouds (PSCs), which facilitate polar springtime ozone depletion (Kirk-Davidoff et al., 1999; MacKenzie et al., 2004; Stenke and Grewe, 2005). SWV owes its existence primarily to transport from the troposphere, which occurs predominantly through the tropical cold-point tropopause (CPT) (Brewer, 1949; Holton and Gettelman, 2001) and to methane oxidation via Reaction (R1) (Bates and Nicolet, 1950; Le Texier et al., 1988):

$\mathrm{CH}_{4}+\mathrm{OH} \rightarrow \mathrm{CH}_{3}+\mathrm{H}_{2} \mathrm{O}$.

Methane oxidation is an important in situ source of water vapour in the middle and upper stratosphere (Brasseur and Solomon, 2005). Further oxidation of the methyl radical $\mathrm{CH}_{3}$ leads to some additional $\mathrm{H}_{2} \mathrm{O}$ formation (although this is limited by the formation of other H-containing molecules, such as $\mathrm{H}_{2}$ or $\mathrm{OH}$ ). Between 1980 and 2010, balloon-borne measurements of SWV over Boulder, Colorado $\left(40^{\circ} \mathrm{N}\right)(\mathrm{Olt}-$ mans and Hofmann, 1995), showed an increase in SWV of $\sim 1 \mathrm{ppmv}$ (almost $30 \%$ ) between 16 and $26 \mathrm{~km}$, with $\sim 0.25 \mathrm{ppmv}$ of the net increase due to increased methane oxidation in the stratosphere (Hurst et al., 2011). This inferred contribution of methane oxidation to the SWV trend is in good agreement with an earlier analysis (Rohs et al., 2006) of balloon-borne SWV measurements from Japan, France and Sweden, with launch sites between 39 and $68^{\circ} \mathrm{N}$. Rohs et al. (2006) concluded that methane contributed $25-34 \%$ to the increase in water vapour in the middle stratosphere between 1978 and 2003 and a smaller amount (1.6-10.7\%) in the lower stratosphere. The remaining increase was attributed to 
increased transport of water vapour from the troposphere to the stratosphere. More recently, Hegglin et al. (2014) showed that merged SWV observations from various satellite data sets display positive trends globally in the upper stratosphere due to methane increases and changes in stratospheric circulation but negative trends in the lower stratosphere.

Austin et al. (2007) also investigated the causes of past changes in SWV but used a coupled chemistry-climate model (CCM) to do so. In contrast to the measurement-based studies of Hurst et al. (2011) and Rohs et al. (2006), they found that methane oxidation was primarily responsible for elevated SWV concentrations between 1960 and 2000. However, their model exhibited a tropical tropopause cold bias of 3-4 K (Eyring et al., 2006), and SWV concentrations in the lower stratosphere were about $30 \%$ lower than expected from observations, implying that too little water vapour entered the stratosphere through the tropical CPT.

The minimum temperature experienced along air parcel trajectories transiting the tropical tropopause into the stratosphere (the CPT) exerts a strong influence on water vapour concentrations in the lower stratosphere (Randel et al., 2004; Fueglistaler et al., 2005; Garcia et al., 2007). Through the 21 st century, the CPT is projected to warm (Gettelman et al., 2010), and therefore water vapour concentrations are expected to increase in the lower stratosphere. Transport and evaporation of ice through the tropical tropopause is also a significant process that controls the amount of water vapour entering the stratosphere (Dessler et al., 2016). Because SWV is a greenhouse gas, increasing lower stratospheric humidity is anticipated to lead to further warming of the troposphere; Dessler et al. (2013) estimate that the climate sensitivity of this feedback is $0.3 \mathrm{~W} \mathrm{~m}^{-2} \mathrm{~K}^{-1}$, with approximately $0.1 \mathrm{~W} \mathrm{~m}^{-2} \mathrm{~K}^{-1}$ coming from increases in SWV through the CPT and the rest coming from increases in water vapour entering the lowermost stratosphere through the extratropical tropopause.

Climate models project that increasing surface temperatures will increase the rate of tropical upwelling (Butchart and Scaife, 2001; Butchart et al., 2010). This means that more methane enters the stratosphere, which will further affect SWV (Austin et al., 2007). However, enhanced tropical upwelling will not necessarily lead to increases in SWV as adiabatic expansion of the tropical tropopause layer cools the CPT (Randel et al., 2006; Dhomse et al., 2008).

SWV will also be affected by methane emissions through the 21 st century. Since 1750 , atmospheric methane concentrations have increased by a factor of $\sim 2.5$ (Montzka et al., 2011). The representative concentration pathways (RCPs) used by the Intergovernmental Panel on Climate Change (IPCC) follow a range of methane concentration scenarios through the 21 st century, depending on the assumptions made regarding future emissions mitigation (van Vuuren et al., 2011a). While under the RCP 2.6 scenario methane reduces by one-third below its year 2000 value by 2100 , con- centrations more than double under RCP 8.5 over the same period (see Fig. 8a).

Oman et al. (2008) studied future changes in SWV using a CCM and showed that increasing methane concentrations under the IPCC's SRES A1B scenario for greenhouse gases (Nakicenovic and Swart, 2000) drove the majority of the simulated increase in SWV until the mid-21st century. The methane effect had a greater effect on SWV increases compared with direct water vapour injections following a warming of the tropical tropopause or a widening of the tropical upwelling (Rosenlof, 2002). Although methane concentrations under the A1b scenario decrease through the second half of the 21st century, expected decreases in SWV were balanced by increased tropical upwelling, leading to a nearzero trend.

Clearly future SWV trends are closely linked to future methane emissions, however little attention has been paid to the effects that a range of methane scenarios may have on SWV evolution. Here we use CCM simulations to first isolate methane's chemical contribution to SWV from climate effects, then show projections of SWV following the four RCPs in the 21 st century and methane's contribution to these projections.

\section{Computational methods}

Model simulations were performed with version 3 of the SOCOL (SOlar Climate Ozone Links) CCM (Stenke et al., 2013; Revell et al., 2015). SOCOL v.3 consists of MAECHAM5, which is the middle atmosphere version of the ECHAM general circulation model (Roeckner et al., 2003), and the MEZON chemistry model (Egorova et al., 2003). For the current study, the model was run as described by Revell et al. (2015), i.e. with T42 horizontal resolution (grid cell sizes correspond to approximately $\left.2.8^{\circ} \times 2.8^{\circ}\right)$ and 39 vertical levels between Earth's surface and $0.01 \mathrm{hPa}(\sim 80 \mathrm{~km})$.

Cloud and ice formation and sedimentation is handled by the MA-ECHAM5 cloud scheme as described by Roeckner et al. (2003), except for in the polar lower stratosphere (that is, above the tropopause poleward of $50^{\circ}$ ). Here, ice formation and sedimentation is handled by SOCOL v.3's PSC scheme, which is necessary to avoid "normal" cirrus formation in PSC regions by the MA-ECHAM5 cloud scheme and to ensure consistent treatment of PSCs in the model. This is a different approach to that used in SOCOL v.2 (Schraner et al., 2008), which participated in CCMVal-2 (SPARC CCMVal$2,2010)$. SOCOL v.3 produces a more realistic simulation of water vapour than v.2, as shown by Stenke et al. (2013).

The model simulations presented here (with the exception of the RCP 6.0-fEmis- $\mathrm{fCH}_{4}$ simulation; see Table 1) were performed in support of phase one of the IGAC/SPARC Chemistry-Climate Model Initiative (CCMI-1) (Eyring et al., 2013; CCMI, 2015). Boundary conditions conform to CCMI-1 requirements and are summarized in Table 1. All 

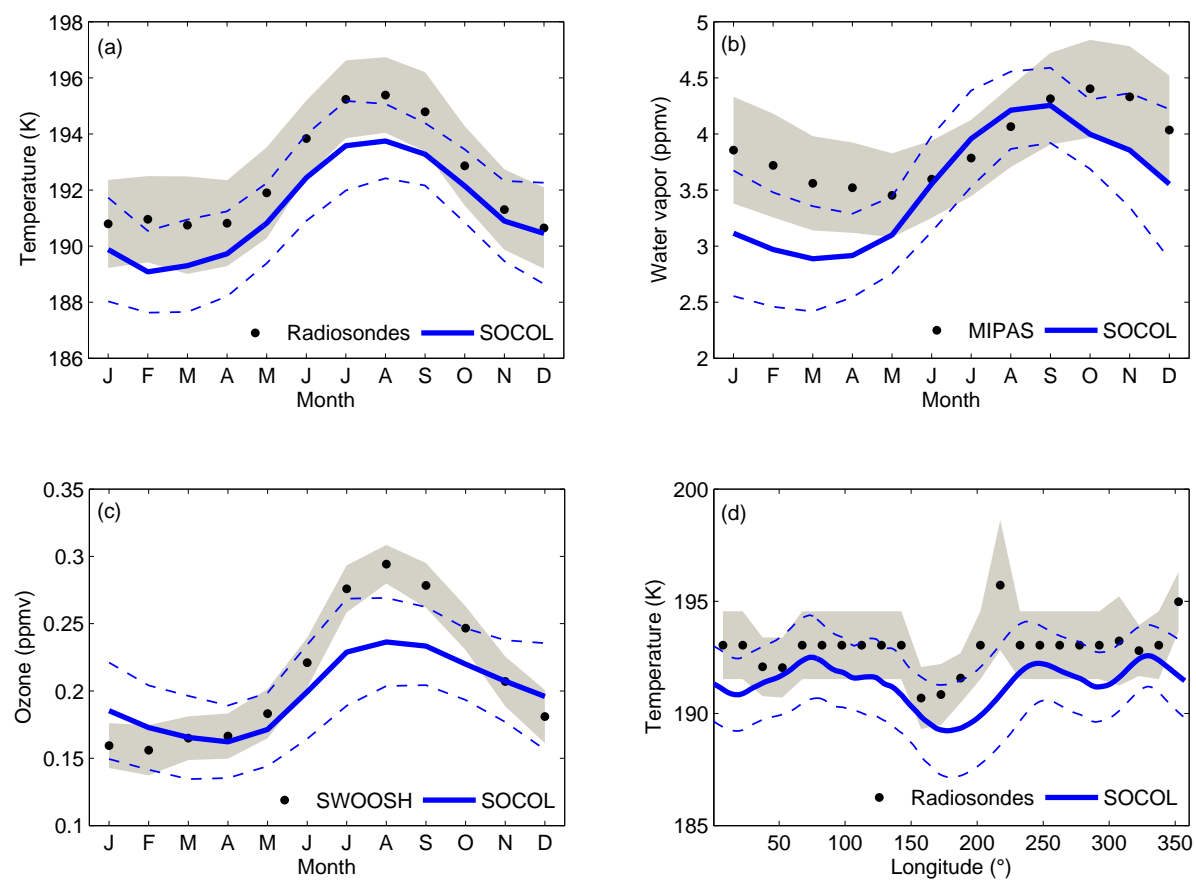

Figure 1. Modelled equatorial temperature, water vapour and ozone from the SOCOL v.3 RCP 6.0 simulation compared with observations. (a) Climatological-mean modelled $\left(4.2^{\circ} \mathrm{N}-4.2^{\circ} \mathrm{S}\right) \mathrm{CPT}$ temperature $(90 \mathrm{hPa})$ compared with radiosonde measurements of the CPT $\left(5^{\circ} \mathrm{N}-5^{\circ} \mathrm{S}\right)$ between 1961 and 1997. (b) Climatological-mean modelled $\left(4.2^{\circ} \mathrm{N}-4.2^{\circ} \mathrm{S}\right)$ water vapour concentrations compared with MIPAS measurements $\left(7.5^{\circ} \mathrm{N}-7.5^{\circ} \mathrm{S}\right)$ between 2005 and 2012 at $80 \mathrm{hPa}$. (c) Climatological-mean modelled $\left(4.2^{\circ} \mathrm{N}-4.2^{\circ} \mathrm{S}, 90 \mathrm{hPa}\right)$ annual cycle in ozone compared with merged SWOOSH observations $\left(3.75^{\circ} \mathrm{N}-3.75^{\circ} \mathrm{S}, 82.5 \mathrm{hPa}\right.$ ) between 1984 and 2015. (d) Annual-mean modelled equatorial CPT temperature $(90 \mathrm{hPa})$ compared with radiosonde measurements of the CPT as a function of longitude. The grey shaded areas represent 1 standard deviation either side of the observations and the dashed blue lines indicate 1 standard deviation either side of model data.

simulations used the World Meteorological Organization's (WMO) A1 scenario for ozone-depleting substances (World Meteorological Organization, 2011). Greenhouse gases (including carbon dioxide, nitrous oxide, methane and halocarbons) were prescribed as surface concentrations, while ozone precursor gases (including nitrogen oxides, carbon monoxide and non-methane volatile organic compounds) were prescribed as emission fluxes. Sea surface temperatures were prescribed following output from the CESM1(CAM5) Earth system model (Meehl et al., 2013). Year 2000 stratospheric aerosol surface area densities and optical parameters were prescribed from the SAGE_4 $\lambda$ data set (Arfeuille et al., 2013; Luo, 2013) for each year of all of the simulations, as the year 2000 was a volcanically quiescent time.

\section{Results and discussion}

\subsection{Comparison with observations}

First, we assess the fidelity of SOCOL v.3's simulation of water vapour, temperature and methane through comparison with observations. Although Stenke et al. (2013) rigorously evaluated SOCOL v.3 in this respect, the model formula- tion was updated for CCMI leading to some important differences in the output. Notably, the update of reaction rate coefficients to the most recent recommendations by Sander et al. (2011) leads to suppressed $\mathrm{HO}_{x}\left(\mathrm{H}+\mathrm{OH}+\mathrm{HO}_{2}\right)$ formation and, therefore, increased stratospheric ozone and extra warming in the upper stratosphere and mesosphere. Overall the extra warming in the current model version leads to better agreement between modelled and observed upper atmospheric temperatures than previous model formulations (not shown). In addition, the parameterization of shortwave heating by $\mathrm{O}_{2}$ and $\mathrm{O}_{3}$ absorption in the mesosphere, applied in Stenke et al. (2013), was updated and extended according to Sukhodolov et al. (2014), which also contributes to warming in the mesosphere.

Figure 1 examines dehydration processes near the tropical tropopause by comparing the modelled annual cycle in equatorial temperature and water vapour at the CPT with observations. In SOCOL v.3 the WMO-defined tropopause (the lowest level at which the lapse rate decreases to $2{ }^{\circ} \mathrm{C} \mathrm{km}^{-1}$ or less) typically lies near $100 \mathrm{hPa}$ in the tropics, while the CPT is typically located at a lower pressure of $90 \mathrm{hPa}$. Figure 1a compares modelled CPT temperatures with radiosonde measurements (Seidel et al., 2001). Between Jan- 
Table 1. Summary of boundary conditions used for the SOCOL v.3 CCM simulations.

\begin{tabular}{|c|c|c|c|c|}
\hline Simulation & Period & Greenhouse gases & Ozone precursor emissions & Sea surface temperatures \\
\hline RCP 2.6 & $2000-2100$ & $\begin{array}{l}\text { Observations } \\
\text { until } 2005 \\
\text { then RCP } 2.6^{\mathrm{a}}\end{array}$ & RCP 2.6 & $\mathrm{RCP} 2.6$ \\
\hline $\mathrm{RCP} 4.5$ & $2000-2100$ & $\begin{array}{l}\text { Observations } \\
\text { until } 2005 \\
\text { then RCP } 4.5^{b}\end{array}$ & $\mathrm{RCP} 4.5$ & RCP 4.5 \\
\hline RCP 6.0 & $1960-2100$ & $\begin{array}{l}\text { Observations } \\
\text { until } 2005 \\
\text { then RCP } 6.0^{c}\end{array}$ & $\begin{array}{l}\text { Historical emissions } \\
\text { until } 2000^{\mathrm{d}} \text { then } \\
\text { RCP } 6.0\end{array}$ & CESM1(CAM5) \\
\hline $\begin{array}{l}\text { RCP } 6.0 \\
\text {-fEmis }\end{array}$ & $1960-2100$ & $\begin{array}{l}\text { Same as } \\
\text { RCP } 6.0\end{array}$ & $\begin{array}{l}\text { Fixed at } \\
1960 \text { levels }\end{array}$ & $\begin{array}{l}\text { Same as } \\
\text { RCP } 6.0\end{array}$ \\
\hline $\begin{array}{l}\text { RCP } 6.0 \\
\text {-fEmis-fCH } 4\end{array}$ & $1960-2100$ & $\begin{array}{l}\text { Same as RCP } 6.0 \\
\text { for } \mathrm{CO}_{2} \text { and } \mathrm{N}_{2} \mathrm{O} \text {; } \\
\mathrm{CH}_{4} \text { fixed at } \\
1960 \text { levels }\end{array}$ & $\begin{array}{l}\text { Fixed at } \\
1960 \text { levels }\end{array}$ & $\begin{array}{l}\text { Same as } \\
\text { RCP } 6.0\end{array}$ \\
\hline RCP 8.5 & $2000-2100$ & $\begin{array}{l}\text { Observations } \\
\text { until } 2005 \\
\text { then RCP } 8.5^{\mathrm{f}}\end{array}$ & $\mathrm{RCP} 8.5$ & RCP 8.5 \\
\hline
\end{tabular}

uary and September the modelled temperatures are $1-2 \mathrm{~K}$ colder than observations, although they agree within 1 standard deviation and are in closer agreement for the remainder of the year. Modelled temperatures in the tropical lower stratosphere reflect the behaviour of the Brewer-Dobson circulation well; a colder environment is simulated during the boreal cold period when the Brewer-Dobson circulation is stronger. The same feature in the seasonal behaviour of ozone is also well simulated, as shown in Fig. 1c, which compares modelled ozone with the Stratospheric Water and Ozone Satellite Homogenized (SWOOSH) data set (Davis et al., 2016). Modelled water vapour entering the stratosphere agrees with the Michelson Interferometer for Passive Atmospheric Sounding (MIPAS) observations (Schieferdecker et al., 2015) within 1 standard deviation (Fig. 1b). However, the modelled annual cycle is shifted such that the annual maximum occurs a month earlier, in September rather than October (discussed further below), and SOCOL exhibits an almost $25 \%$ negative bias compared with observations between January and April. Another possible reason for the phase shift may be the lower vertical resolution of the satellite data set.

Figure 2 compares modelled water vapour with MIPAS observations higher in the atmosphere. Modelled water vapour profiles generally show good agreement with observations (Fig. 2a-c), although the modelled equatorial stratosphere at $30 \mathrm{hPa}$ is up to $20 \%(0.78 \mathrm{ppmv})$ too moist, depending on the season (Fig. 2b). As demonstrated by the tropical CPT temperatures in Fig. 1a (the annual cycle) and 1d (annual-mean temperature as a function of longitude), a too-moist stratosphere cannot be due to excess water vapour entering the stratosphere via the CPT as the modelled CPT is cold-biased. Furthermore, the annual cycle in the lower-tomiddle stratosphere is out of phase compared with observations (Fig. 2d). The annual cycle in water vapour progresses with decreasing pressure (Randel et al., 1998), and because SOCOL v.3 has too-fast upward propagation as estimated from the water vapour tape recorder (Stenke et al., 2013), seasonal variability is shifted upwards such that maximum water vapour mixing ratios occur out of phase with observations. However, when examining the annual mean, SOCOL v.3 compares favourably with observations (Fig. 2e).

In the upper stratosphere, $\mathrm{SWV}$ is produced as a result of methane oxidation. SOCOL v.3 is in good agreement with observations within 1 standard deviation throughout the stratosphere (Fig. 3), except above $2 \mathrm{hPa}$ in the equatorial atmosphere (Fig. 3b), where it exhibits a positive bias in methane of $\sim 50 \%$ compared to HALOE observations (Grooß and Russell, 2005). Recently, Laeng et al. (2015) and Plieninger et al. (2016) have shown that HALOE may be low biased compared to other satellite methane observations in the upper stratosphere and lower mesosphere. In this region of the atmosphere, SOCOL v.3 agrees favourably with MIPAS observations (not shown). 

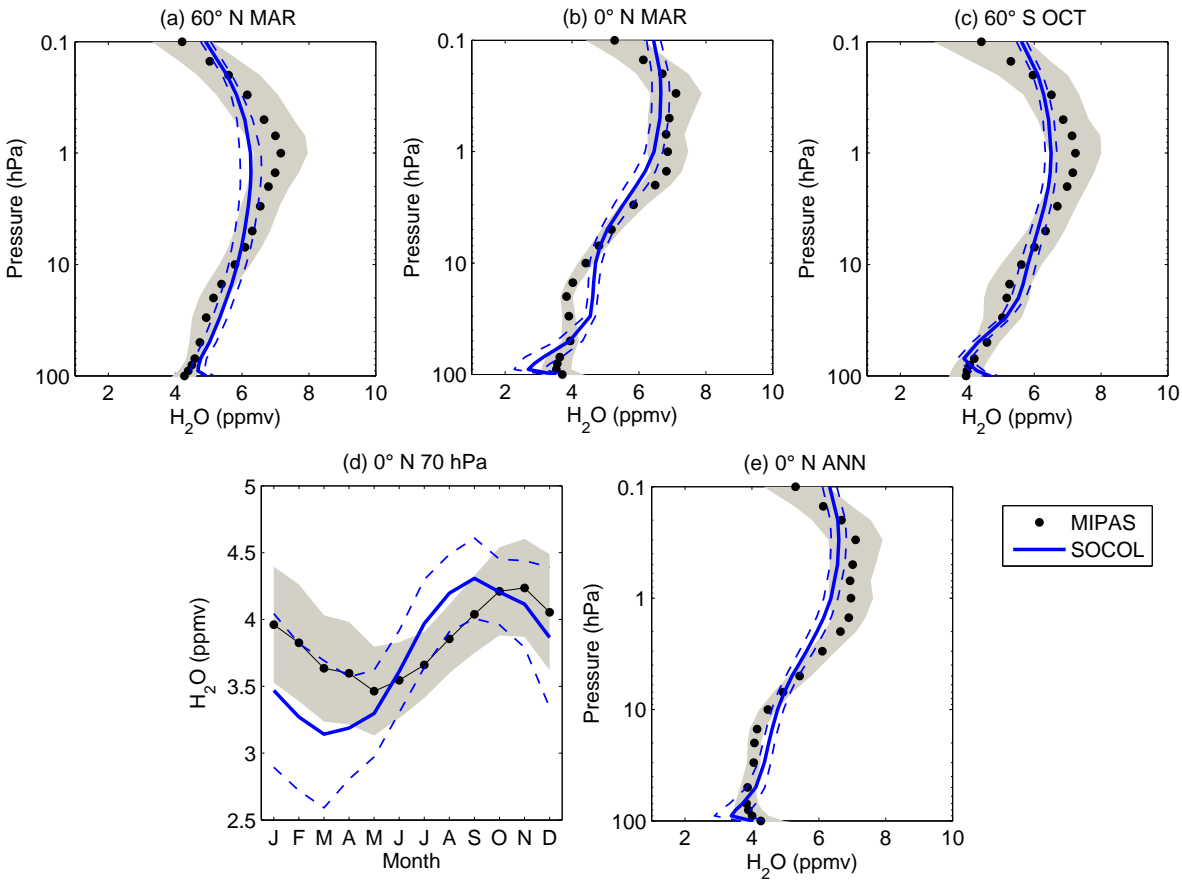

Figure 2. Modelled water vapour from the SOCOL v.3 RCP 6.0 simulation compared with MIPAS observations (climatological means for 2005-2012) for (a) $60^{\circ} \mathrm{N}$, March; (b) the Equator, March; (c) $60^{\circ} \mathrm{S}$, October; (d) the Equator, $70 \mathrm{hPa}$; and (e) the Equator, annual mean. The grey shaded areas represent 1 standard deviation either side of observations and the dashed blue lines represent 1 standard deviation either side of model data.
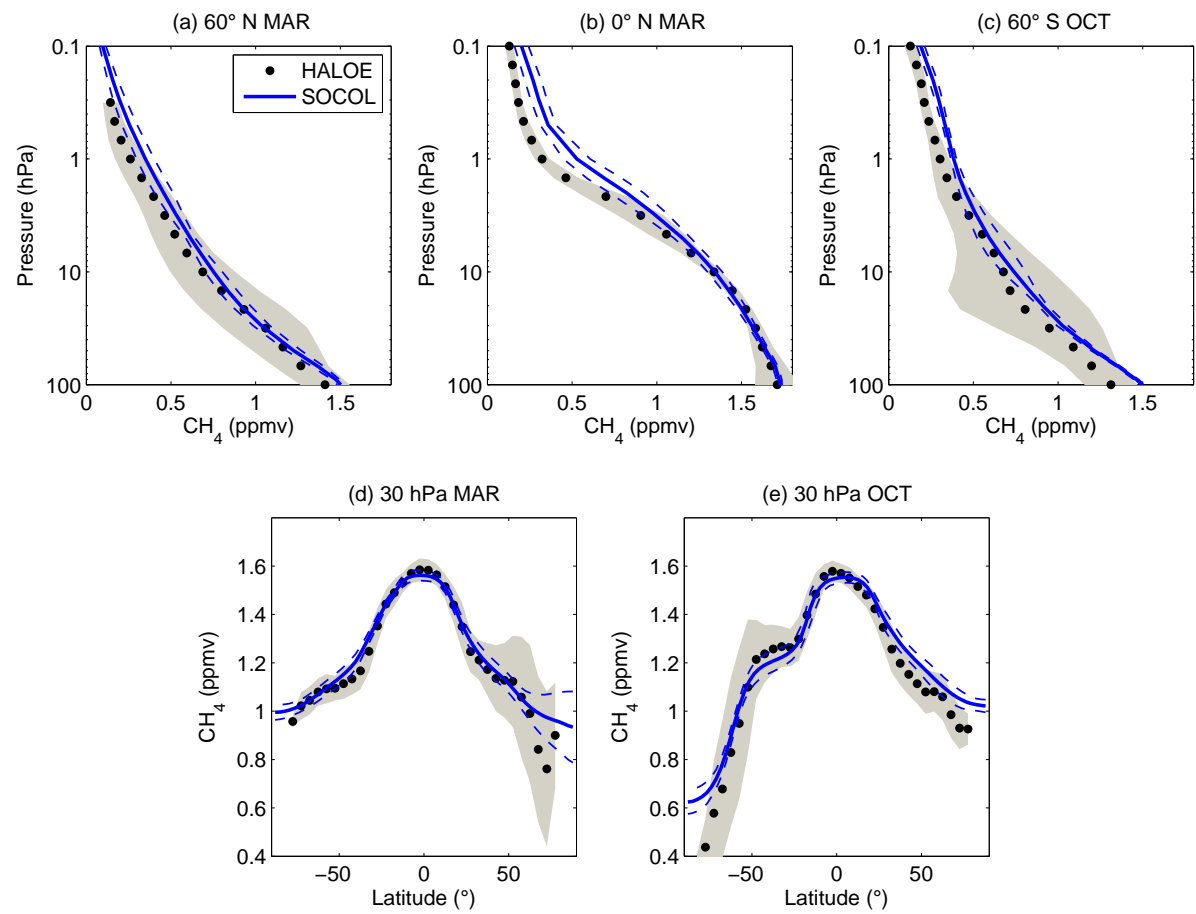

Figure 3. Modelled methane concentrations from the SOCOL v.3 RCP 6.0 simulation compared with HALOE observations (climatological means for 1991-2002) for (a) $60^{\circ} \mathrm{N}$, March; (b) the Equator, March; (c) $60^{\circ} \mathrm{S}$, October; (d) $30 \mathrm{hPa}$, March; (e) $30 \mathrm{hPa}$, October. The grey shaded areas represent 1 standard deviation either side of observations and the dashed blue lines represent 1 standard deviation either side of model data. 

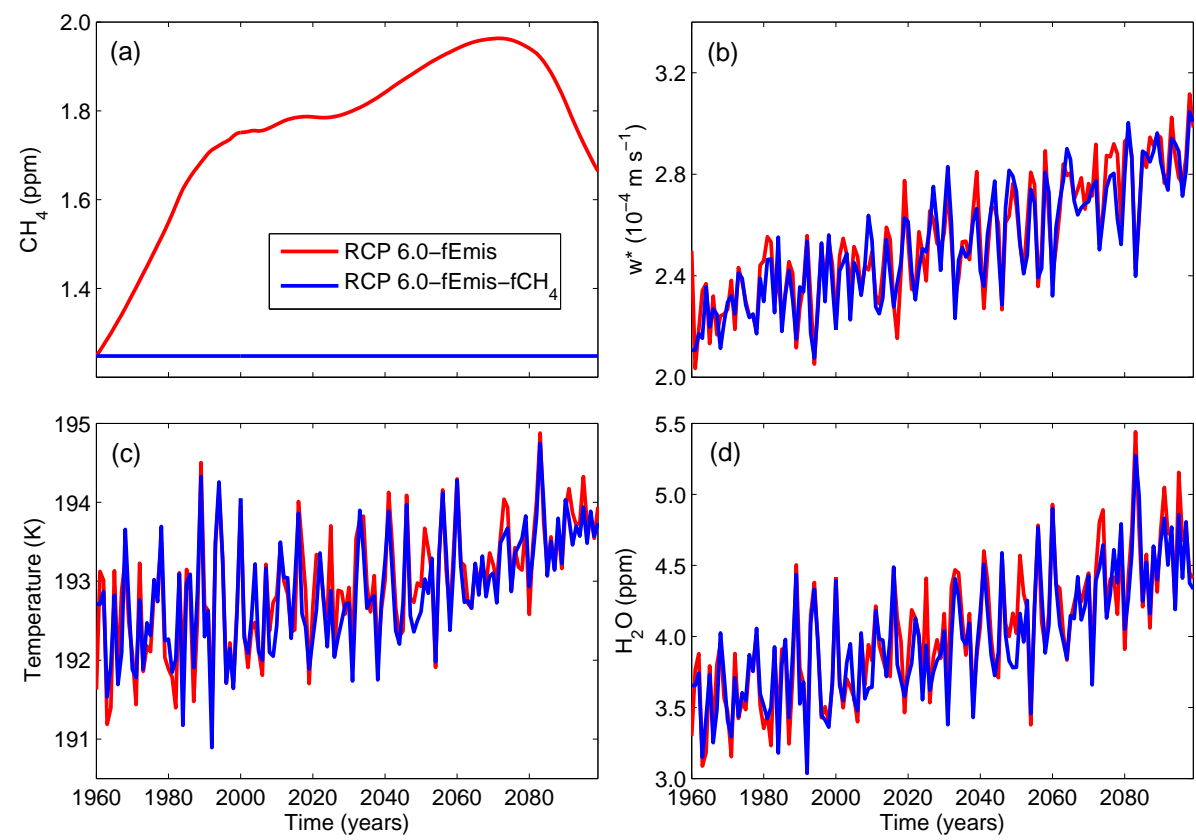

Figure 4. Drivers of SWV change in the RCP 6.0-fEmis and RCP 6.0-fEmis-fCH4 simulations. (a) Global-mean and annual-mean surface methane concentrations. (b) Annual-mean rate of the vertical residual circulation at $70 \mathrm{hPa}, 20^{\circ} \mathrm{N}-20^{\circ} \mathrm{S}$. (c) Annual-mean tropical CPT temperatures, $20^{\circ} \mathrm{N}-20^{\circ} \mathrm{S}, 90 \mathrm{hPa}$. (d) Annual-mean stratospheric entry water vapour at $80 \mathrm{hPa}, 20^{\circ} \mathrm{N}-20^{\circ} \mathrm{S}$.

\subsection{Drivers of SWV change}

Drivers of SWV change are shown in Fig. 4 for the RCP 6.0-fEmis and RCP 6.0-fEmis- $\mathrm{fCH}_{4}$ simulations. These simulations are both based on RCP 6.0, although tropospheric ozone precursor emissions (including nitrogen oxides, nonmethane volatile organic compounds and carbon monoxide) are held constant at 1960 levels (Table 1). Therefore, in the stratosphere RCP 6.0-fEmis is very similar to RCP 6.0 (at least in terms of SWV). The only difference between the RCP 6.0-fEmis and RCP 6.0-fEmis- $\mathrm{fCH}_{4}$ simulations is that methane is kept at constant 1960 concentrations throughout the RCP 6.0-fEmis- $-\mathrm{fCH}_{4}$ simulation, while in the RCP 6.0fEmis simulation methane follows RCP 6.0 (Fig. 4a). Comparing RCP 6.0-fEmis and RCP 6.0-fEmis- $\mathrm{fCH}_{4}$ therefore isolates the chemical impact of methane on SWV.

Figure $4 \mathrm{~b}$ shows that the rate of tropical upwelling is projected to increase through the 21st century, as simulated by other CCMs (Butchart et al., 2010; SPARC CCMVal-2, 2010). Stronger tropical upwelling transports more methane from the troposphere into the stratosphere where it undergoes subsequent oxidation to water vapour via Reaction (R1) (Austin et al., 2007). Stronger tropical upwelling has also been shown to lead to reduced ozone concentrations in the tropical lower stratosphere (Bekki et al., 2013), resulting in cooling of the CPT and subsequent decreases in SWV (Randel et al., 2006; Dhomse et al., 2008). Although tropical lower stratospheric ozone decreases over time in our model simulations (not shown), we see increases in both annual- mean temperatures at the CPT (Fig. 4c) and water vapour concentrations just above the tropical CPT (Figure 4d). Between 1960 and 2100, annual-mean CPT temperatures increase by approximately $1.35 \mathrm{~K}$ in the RCP 6.0 -fEmis and RCP 6.0-fEmis- $\mathrm{fCH}_{4}$ simulations (Fig. 4c), resulting in an increase in stratospheric entry water vapour of approximately 1.05 ppmv $(\sim 30 \%)$ over the same period. These changes are similar to those simulated by the CCMVal-2 models, which projected increases in the CPT temperature and stratospheric entry water vapour of $\sim 1.4 \mathrm{~K}$ and $0.7-1.4 \mathrm{ppmv}$, respectively, between 1960 and 2100 (Gettelman et al., 2010), following the IPCC's SRES A1B scenario for greenhouse gases (which is similar to RCP 6.0 in terms of greenhouse gas concentrations) (Nakicenovic and Swart, 2000). Increases in the amount of water vapour entering the stratosphere are also linked with El Niño-Southern Oscillation conditions (Scaife et al., 2003), which occur more frequently throughout the 21 st century under RCP 6.0.

\subsection{Impacts of methane and climate change on SWV}

Figure 5a shows the change in SWV between the 1960s and 2090s of the RCP 6.0-fEmis- $\mathrm{fCH}_{4}$ simulation. SWV increases by $\sim 1$ ppmv (or $20 \%$ ) through much of the stratosphere with the exception of the Antarctic lower stratosphere. Here, there is no change in SWV because this region is near saturation during winter, and so as the stratosphere cools through the 21 st century more irreversible loss of SWV occurs, thus cancelling out increases in water vapour entering 

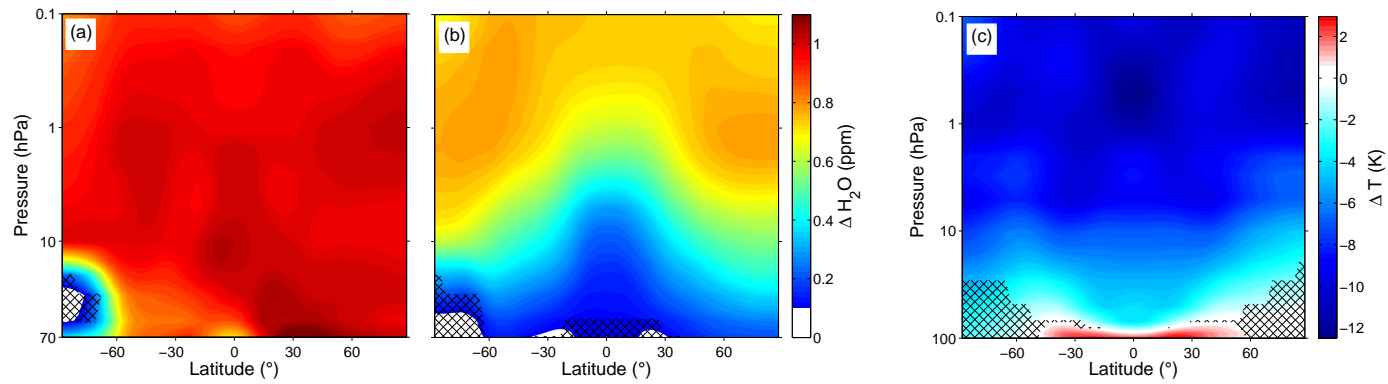

Figure 5. Impact of changes in climate and methane on SWV: (a) Increase in water vapour between the 1960s and 2090s in the RCP 6.0-fEmis- $\mathrm{fCH}_{4}$ simulation (2090s minus 1960s); (b) increase in water vapour in the 2090s decade between the RCP 6.0-fEmis and RCP 6.0-fEmis- $\mathrm{fCH}_{4}$ simulations (RCP 6.0-fEmis minus RCP 6.0-fEmis- $\mathrm{fCH}_{4}$ ); and (c) zonal-mean temperature change in the RCP 6.0-fEmis$\mathrm{fCH}_{4}$ simulation (2090s minus 1960s). Hatching shows where the difference is not statistically significant at the $95 \%$ level of confidence, calculated with Student's $t$ test.

the stratosphere (Oman et al., 2008; Dessler et al., 2013). The $\sim 1$ ppmv change in SWV seen between 1960 and 2100 is fairly uniform throughout most of the stratosphere as transport within the stratosphere leads to homogenization at a faster rate than the rate at which entry water vapour changes (Dessler et al., 2013).

As methane concentrations were kept constant in the RCP 6.0-fEmis- $\mathrm{fCH}_{4}$ simulation, the contribution of methane oxidation to changes in SWV is excluded. Potential drivers of the SWV changes shown in Fig. 5a therefore result from some combination of increasing CPT temperatures allowing more water vapour to enter the stratosphere, the strengthening Brewer-Dobson circulation transporting more methane into the stratosphere where it undergoes oxidation to SWV and temperature-induced changes in the rate of methane oxidation. Between 1960 and 2100, stratospheric and mesospheric temperatures are projected to decrease, with a maximum cooling of $12 \mathrm{~K}$ projected for the mesosphere in the RCP 6.0-fEmis- $\mathrm{fCH}_{4}$ simulation (Fig. 5c). As a result, the rate constant for Reaction (R1) is projected to slow by up to $3.5 \%$ in the upper stratosphere (not shown). We therefore do not expect temperature-induced changes in the rate of methane oxidation to significantly influence future SWV changes.

Dessler et al. (2013) showed the change in SWV over the 21 st century with the contribution from methane oxidation removed (by assuming that each methane molecule destroyed produces two water molecules). This is akin to looking at the change in SWV in our RCP 6.0-fEmis-fCH simulation (Fig. 5a), and indeed the results are very similar, with both the GEOSCCM (Goddard Earth Observing System Chemistry Climate Model, used by Dessler et al., 2013) and SOCOL v.3 models simulating an increase in SWV due to climate-related changes of $\sim 1 \mathrm{ppmv}$ through the 21 st century.

Figure $5 \mathrm{~b}$ shows the difference in SWV in the 2090s between the RCP 6.0-fEmis and RCP 6.0-fEmis- $-\mathrm{fCH}_{4}$ simulations. The methane increase that occurs between 1960 and
2100 in the RCP 6.0-fEmis simulation is responsible for statistically significant increases in SWV throughout the upper (and much of the middle) stratosphere, maximizing at approximately $0.8 \mathrm{ppmv}(\sim 12 \%)$ in the extratropical upper stratosphere. Note that in RCP 6.0, the maximum methane concentrations $(\sim 1.97 \mathrm{ppmv})$ occur around 2070 , and by 2100 methane is projected to have decreased to 1980 levels. The contribution of methane to SWV is small and statistically insignificant in the lower stratosphere (noted also by Rohs et al., 2006), which is where SWV exerts the greatest impact on radiative forcing (Solomon et al., 2010).

To summarize, climate-related changes are responsible for an increase in SWV of 1 ppmv between 1960 and 2100. Changes in methane are responsible for an increase of almost a similar magnitude ( $0.8 \mathrm{ppmv})$ but only in the upper stratosphere; closer to the tropopause methane does not induce such a large increase in SWV, as found in previous CCM studies (Tian and Chipperfield, 2006; Oman et al., 2008).

\subsection{Projections for the RCPs}

While the simulations discussed so far (RCP 6.0-fEmis and RCP 6.0-fEmis- $\mathrm{fCH}_{4}$ ) are both based on RCP 6.0, methane follows different concentration pathways in the other RCPs (Fig. 8a). To isolate the effect of methane in the other RCPs, we approximated SWV in a way similar to Austin et al. (2007) and Oman et al. (2008):

$$
\begin{aligned}
\mathrm{H}_{2} \mathrm{O}(\theta, p, t) & =\left.\mathrm{H}_{2} \mathrm{O}\right|_{e}(t-\tau)+2\left[\left.\mathrm{CH}_{4}\right|_{0}(t-\tau)\right. \\
& \left.-\mathrm{CH}_{4}(\theta, p, t)\right],
\end{aligned}
$$

where for each latitude $(\theta)$, pressure level $(p)$ and time $(t)$, $\left.\mathrm{H}_{2} \mathrm{O}\right|_{e}$ is the tropical $\left(10^{\circ} \mathrm{N}-10^{\circ} \mathrm{S}\right)$ water vapour concentration at $70 \mathrm{hPa}, \tau$ is the age of air, and $\left.\mathrm{CH}_{4}\right|_{0}$ is the tropical methane concentration at $150 \mathrm{hPa}$. The first term in Eq. (1) (i.e. $\left.\left.\mathrm{H}_{2} \mathrm{O}\right|_{e}(t-\tau)\right)$ represents water vapour concentrations entering the stratosphere, and the second term represents the contribution to SWV from methane oxidation. The age of air for each latitude, pressure and time $(\tau(\theta, p, t))$ is included 

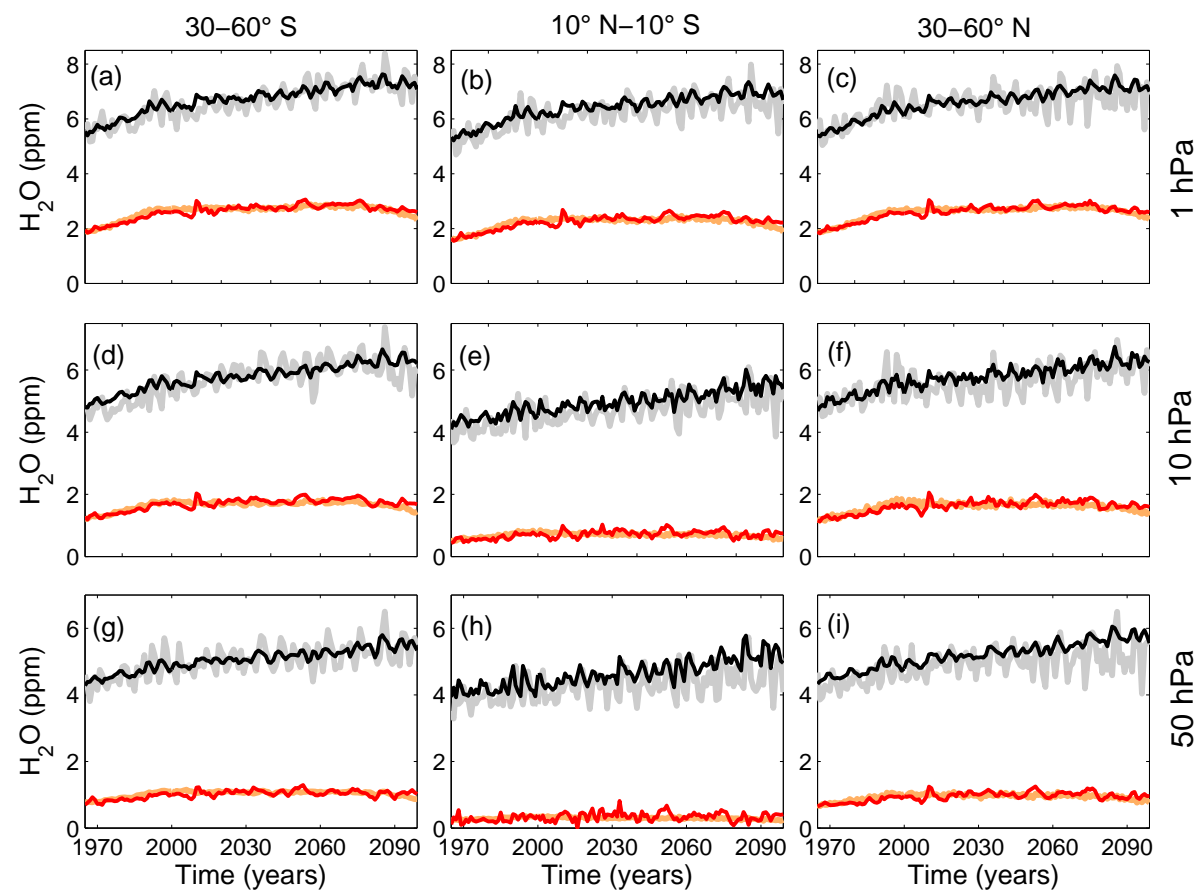

Constructed $\mathrm{H}_{2} \mathrm{O} \longrightarrow$ Actual $\mathrm{H}_{2} \mathrm{O}$

Constructed $\mathrm{CH}_{4}$ contribution

Actual $\mathrm{CH}_{4}$ contribution

Figure 6. Constructed SWV (grey lines), actual SWV (black), the constructed methane contribution (orange) and the actual methane contribution (red) to SWV in the RCP 6.0-fEmis simulation. Top row: upper stratosphere $(1 \mathrm{hPa})$. Centre row: middle stratosphere $(10 \mathrm{hPa})$. Bottom row: lower stratosphere $(50 \mathrm{hPa})$. Left column: southern mid-latitudes $\left(30-60^{\circ} \mathrm{S}\right)$. Centre column: tropics $\left(10^{\circ} \mathrm{N}-10^{\circ} \mathrm{S}\right)$. Right column: northern mid-latitudes $\left(30-60^{\circ} \mathrm{N}\right)$. See text for details on how the methane contributions were calculated. All quantities shown are annual means.
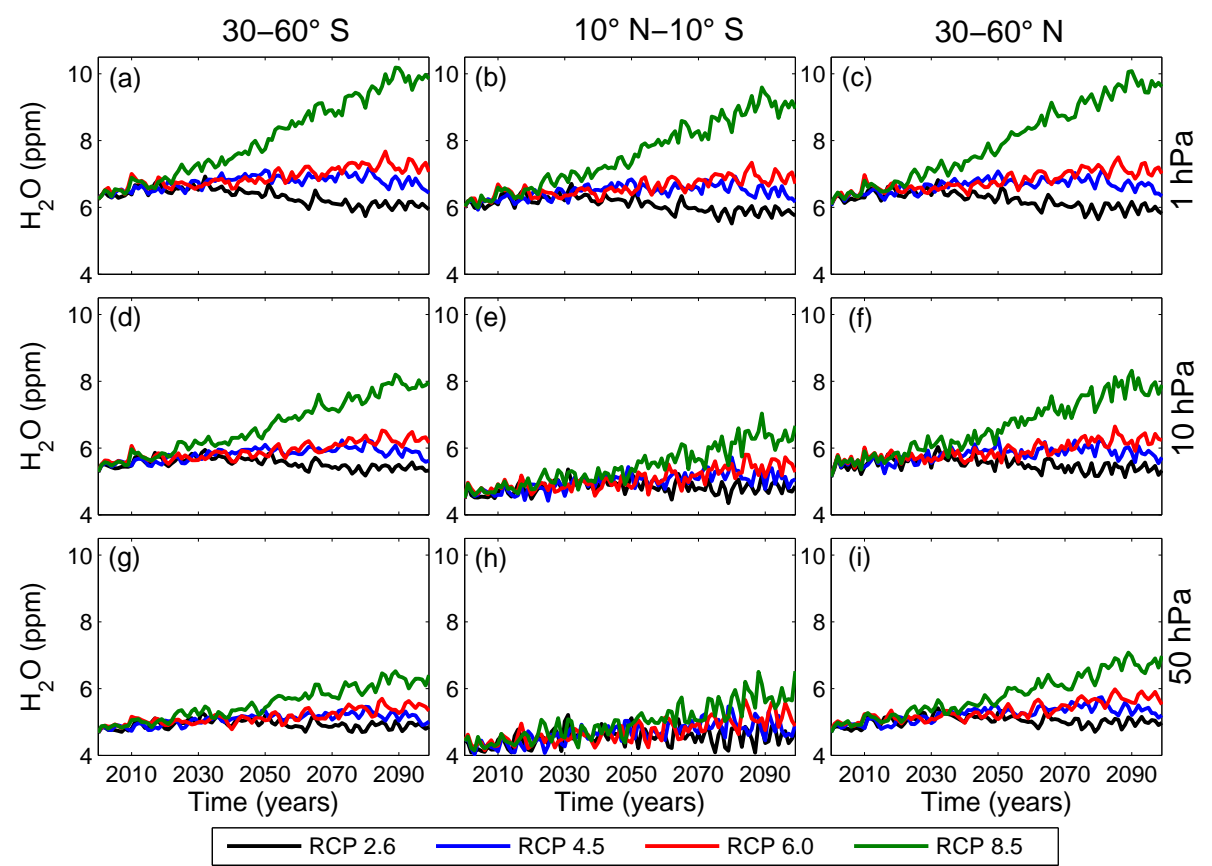

Figure 7. SWV in the four RCP simulations for the same regions shown in Fig. 6. 

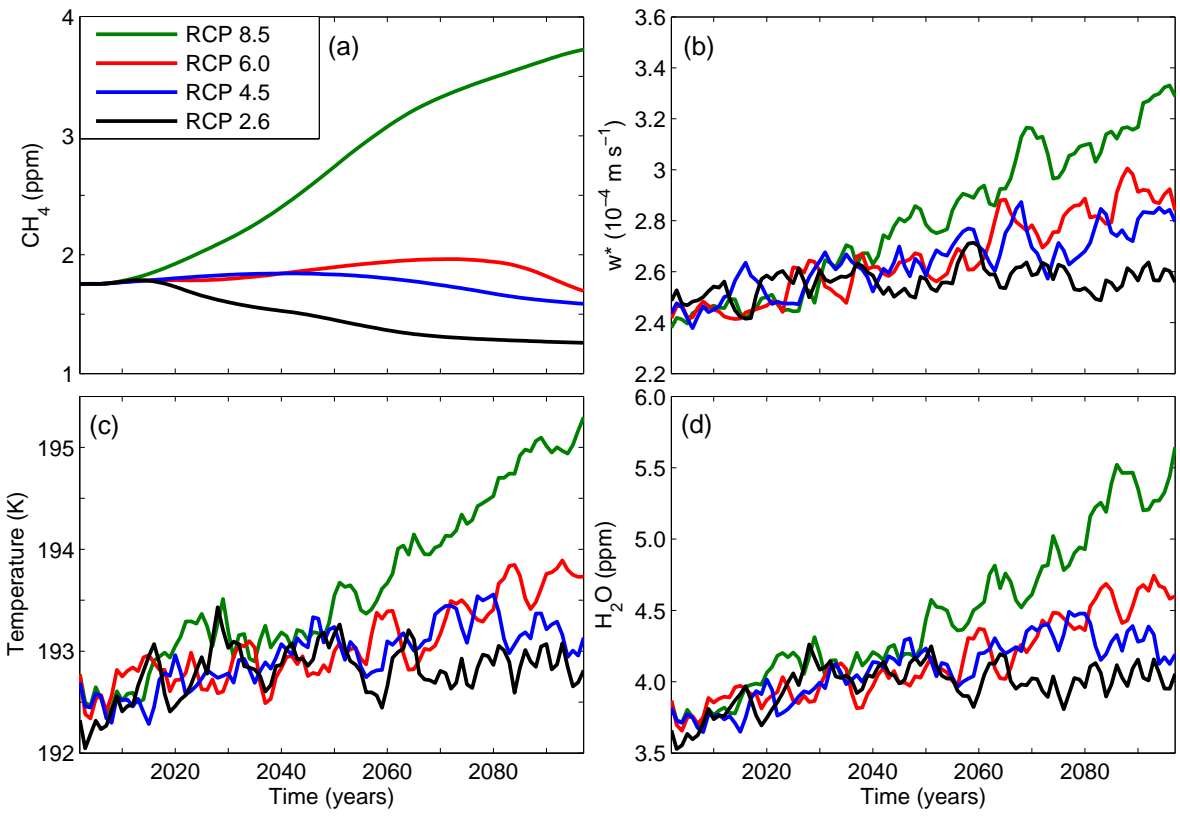

Figure 8. Same as Fig. 4 but showing drivers of SWV change in the RCPs. For clarity, the time series in (b)-(d) have been smoothed with a 5 year running mean.
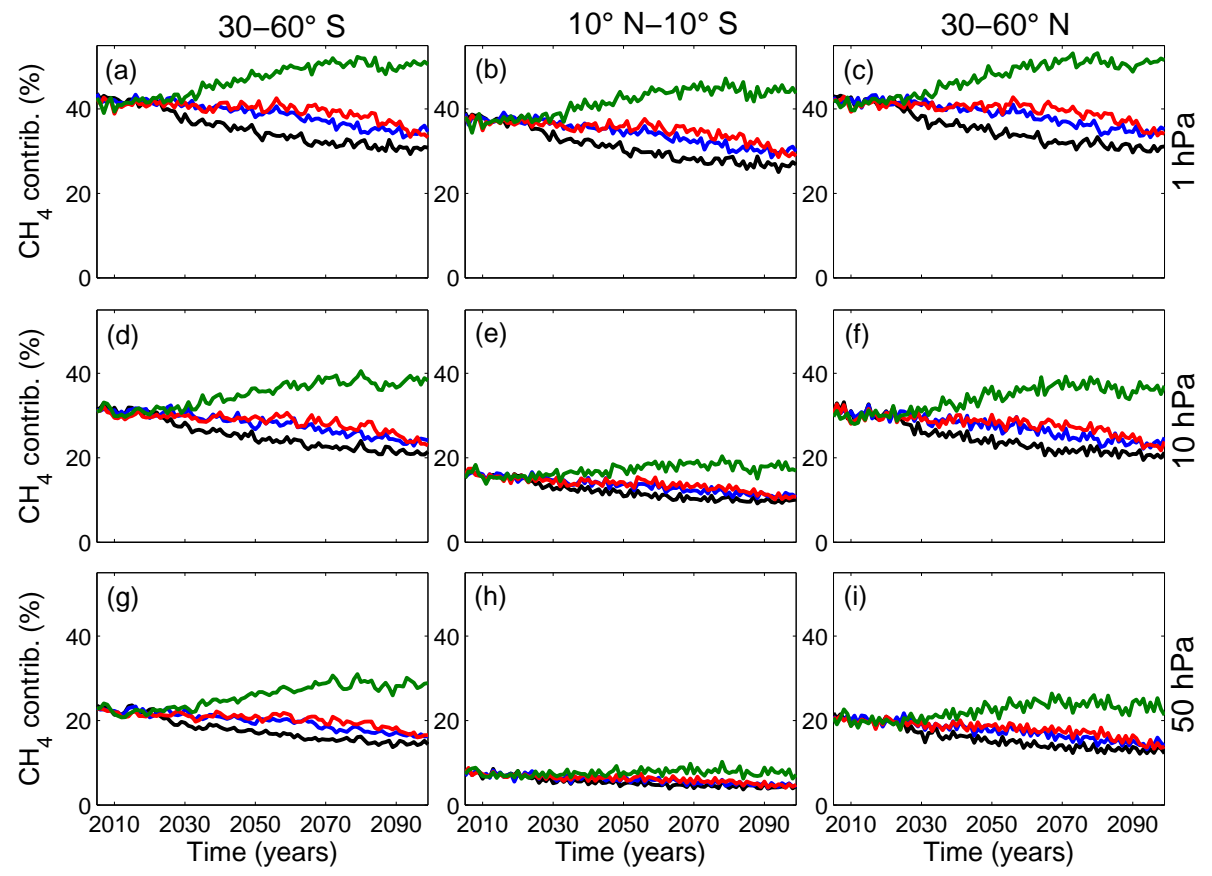

- RCP $2.6-$ RCP $4.5-$ RCP $6.0-$ RCP 8.5

Figure 9. Percentage contribution of methane to SWV in the four RCP simulations for the regions shown in Fig. 6. Methane contributions were calculated as for Fig. 6.

because for a given parcel of air, entry into the stratosphere will have occurred at an earlier time (depending on where the parcel of air is), and the amount of methane oxidation that will have occurred depends on the time since that parcel of air resided in the troposphere (Austin et al., 2007).

To demonstrate the validity of the approximation underlying Eq. (1), SWV constructed using Eq. (1) is compared 

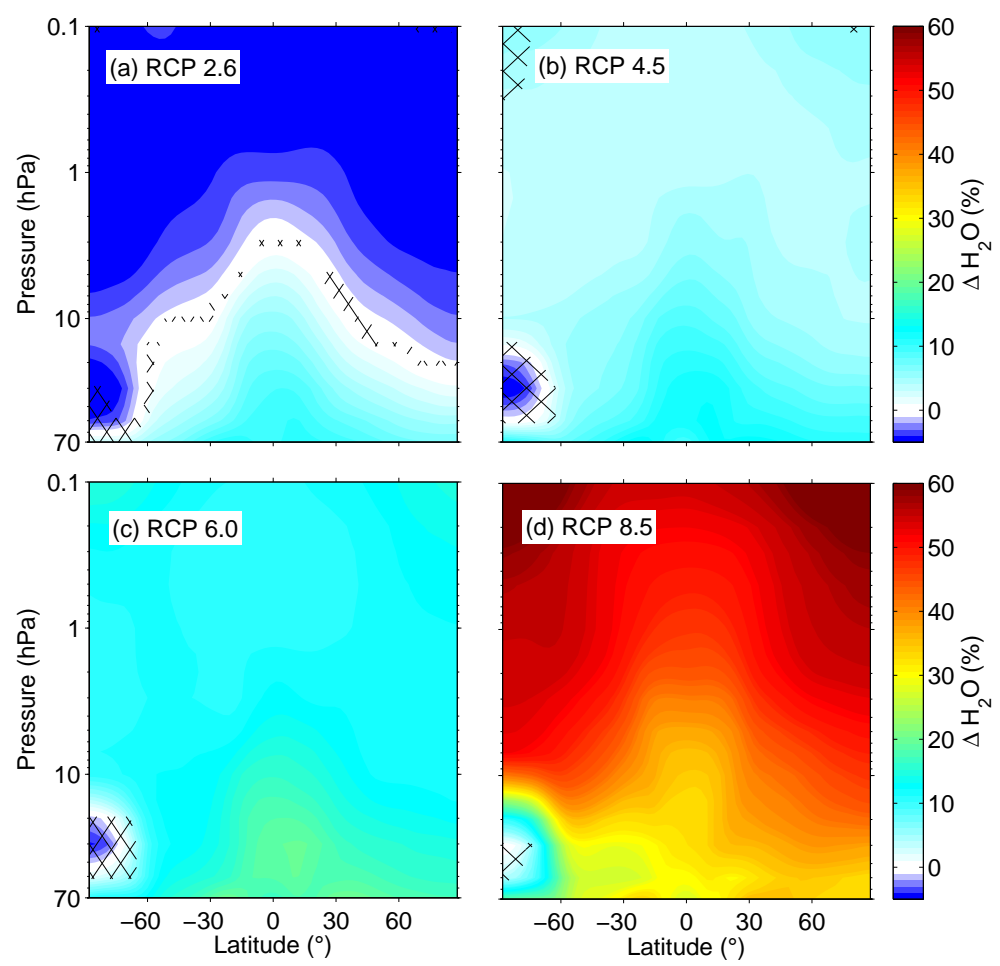

Figure 10. Change in water vapour between the 2000s and 2090s (2090s minus 2000s). Hatching indicates that the difference is not statistically significant at the $95 \%$ level of confidence, calculated with Student's $t$ test.

with actual SWV for the RCP 6.0-fEmis simulation for a range of latitudes and pressure levels (Fig. 6). Constructed SWV shows larger variability than actual SWV because it is constructed using entry water vapour, which exhibits larger modelled variability compared with water vapour higher in the stratosphere. The constructed methane contribution (second term in Eq. 1) is also shown, compared with the actual methane contribution. Because the constructed methane contribution is calculated by subtracting the stratospheric methane concentration (at any location in the stratosphere) from the tropical methane concentration at $150 \mathrm{hPa}$, and because modelled stratospheric methane concentrations become more variable higher in the atmosphere (considering that methane is prescribed as a surface concentration uniformly over the globe), the constructed methane contributions in Fig. 6 exhibit greater variability than the actual methane contribution. The actual methane contribution is obtained by calculating the difference between SWV in the RCP 6.0-fEmis and RCP 6.0-fEmis- $-\mathrm{fCH}_{4}$ simulations for each month and adding the mean methane contribution for the 1960s (noting that methane oxidation makes a small but not insignificant contribution to SWV in the RCP 6.0-fEmis$\mathrm{fCH}_{4}$ simulation, albeit mostly constant between 1960 and 2100). Methane contributes to approximately one-third of upper stratospheric water vapour in the RCP 6.0-fEmis simulation, although the contribution is smaller in the lower stratosphere, especially in the tropics. Small decreases in the methane contribution are observed after $\sim 2080$ following decreases in surface methane (as prescribed by RCP 6.0).

We now examine SWV in the four RCPs between 2000 and 2100 (Fig. 7). As for Fig. 6, SWV time series constructed with the approximation in Eq. (1) agree well with the actual SWV simulated in the RCPs (not shown). The projections of SWV for RCP 6.0 in Fig. 7 and the RCP 6.0-fEmis simulation in Fig. 6 are very similar as these simulations differ only with respect to tropospheric ozone precursors (Table 1). Large differences in SWV between the RCPs are projected for the end of the 21st century; for example, at $1 \mathrm{hPa}$ SWV is 3-4 ppmv greater in RCP 8.5 compared with RCP 2.6 (depending on latitude) (Fig. 7a-c). Of all the RCPs, the largest increase in SWV through the 21st century at any pressure level and latitude is projected to occur in RCP 8.5. The RCP 8.5 scenario prescribes the largest increase in methane of $\sim 2$ ppmv, or $114 \%$, between 2000-2100 (Fig. 8a), but also the largest increases in the other greenhouse gases (especially $\mathrm{CO}_{2}$ ), which drive a faster rate of tropical upwelling (Fig. 8b) and warm the CPT. Between 2000 and 2100 the CPT warms by $0.7 \mathrm{~K}$ in RCP 2.6 and $2.4 \mathrm{~K}$ in RCP 8.5 (Fig. 8c). Because it warms more, the amount of water vapour entering the stratosphere increases at a larger rate in RCP 8.5 compared with the other RCPs; between the 2000 and 2100 entry SWV increases by $1.6 \mathrm{ppmv}$ ( $42 \%$ ) in RCP 8.5 , compared with 0.4 ppmv (12\%) in RCP 2.6 (Fig. 8d). 
To better understand the contribution that methane makes to SWV concentrations in the RCPs, Fig. 9 shows the methane contribution term (calculated from Eq. 1), expressed as a percentage of SWV. As previously stated, methane makes the largest contribution to the SWV budget in the upper stratosphere ( $\sim 40-50 \%$ following RCP 8.5, Fig. 9ac) and the smallest contribution in the tropical lower stratosphere ( $\sim 4 \%$ following RCP 2.6, Fig. 9h). In all simulations other than RCP 8.5, the fractional contribution of methane to SWV decreases through the 21st century, despite the fact that faster tropical upwelling transports more methane into the stratosphere in all simulations (Fig. 8b). Primarily this is because prescribed surface methane concentrations decrease after approximately 2015, 2050 and 2080 for RCPs 2.6, 4.5 and 6.0 respectively (Fig. 8a). Secondly, the rate of methane oxidation (Reaction R1) is temperature-dependent and slows as the stratosphere cools through the 21 st century, although this is not a significant process as discussed in Sect. 3.3. Finally, under RCP 8.5, more water vapour enters the stratosphere due to warming of the CPT, such that the fractional contribution of methane plateaus. This increase in concentrations of water vapour entering the stratosphere is visible in the tropical lower stratospheric regions of Fig. 10. Indeed, in RCPs 2.6, 4.5 and 6.0, the largest changes in SWV between 2000 and 2100 are due to increasing concentrations of water vapour entering the tropical lower stratosphere, while in RCP 8.5 (Fig. 10d) the largest SWV increase (up to $60 \%$ ) occurs in the extratropical upper stratosphere, and methane is responsible for just over half of that increase (Fig. 9a and c).

The contribution that methane is projected to make to future SWV evolution is dependent on pressure, latitude and the methane growth scenario. The biggest contributions are seen in the upper stratosphere (Fig. 9). All of the RCPs project increases in water vapour entering the stratosphere due to warming of the CPT (Figs. 8c-d and 10). Therefore, future increases in SWV will contribute to global warming, given SWV's role as a greenhouse gas, in agreement with Dessler et al. (2013).

In all of the RCPs other than RCP 2.6, upper SWV concentrations increase (Fig. 10). We therefore expect enhanced rates of the ozone-destroying $\mathrm{HO}_{x}$ cycles, which are fastest in the upper stratosphere, although this will not impact the overall increase in stratospheric ozone projected through the 21st century (Pawson and Steinbrecht, 2014). We do not see an enhancement in lower SWV concentrations over the Antarctic in the RCPs (Fig. 10) because this region is near saturation during winter. Therefore, changes in ozone here will likely be due to factors other than SWV. Revell et al. (2012) showed that, throughout the middle stratosphere, increases in methane and SWV in the RCPs are expected to lead to increased ozone abundances through the 21st century owing in part to SWV-induced cooling of the stratosphere which slows the gas-phase catalytic ozone loss cycles. Such cooling through the 21 st century is also expected to affect circulation patterns in the lower stratosphere and troposphere (Joshi et al., 2006; Maycock et al., 2013).

\section{Conclusions}

We have used the SOCOL v.3 CCM to simulate changes in SWV through the 21st century and attributed these changes to various processes. Concentrations of water vapour entering the tropical lower stratosphere are projected to increase because of warming of the CPT. Between 1960 and 2100 under RCP 6.0, such climate-related changes are projected to lead to increases in water vapour of approximately 1 ppmv throughout the stratosphere, with the exception of the already-saturated Antarctic lower stratosphere. Higher up in the stratosphere, methane oxidation contributes to the SWV burden, although its contribution is highly dependent on latitude, pressure and the methane concentration scenario. In 2100, the largest contribution methane makes to SWV is $\sim 50 \%$ (following RCP 8.5 in the extratropical upper stratosphere) and the smallest contribution is $\sim 4 \%$ (following RCP 2.6 in the tropical lower stratosphere). SWV itself increases everywhere following RCPs 4.5, 6.0 and 8.5 (except in the Antarctic lower stratosphere), with the largest increase of $\sim 60 \%$ occurring in RCP 8.5 in the extratropical upper stratosphere. In RCP 2.6, which represents a low-emissions pathway for future anthropogenic greenhouse gases, SWV decreases by up to $5 \%$ in the upper stratosphere between 2000 and 2100 but increases by up to $10 \%$ in the tropical lower stratosphere. Given that water vapour exerts the largest influence on radiative forcing in the lower stratosphere compared with higher altitudes, SWV's influence on surface climate is expected to increase through the 21 st century following all of the RCPs.

\section{Data availability}

SOCOL v.3 CCMI-1 data are held at the British Atmospheric Data Centre; see http://catalogue.ceda.ac.uk/uuid/ 1005d2c25d14483aa66a5f4a7f50fcf0 (ETH-PMOD, 2015).

Acknowledgements. L. Revell thanks Greg Bodeker for helpful comments on this manuscript. E. Rozanov appreciates support from the Swiss National Science Foundation (SNSF) under grant CRSII2-147659 (FUPSOL II). W. Ball was funded by SNSF grants 200021-149182 (SILA) and 200020-163206 (SIMA).

Edited by: M. Dameris

Reviewed by: two anonymous referees 


\section{References}

Arfeuille, F., Luo, B. P., Heckendorn, P., Weisenstein, D., Sheng, J. X., Rozanov, E., Schraner, M., Brönnimann, S., Thomason, L. W., and Peter, T.: Modeling the stratospheric warming following the Mt. Pinatubo eruption: uncertainties in aerosol extinctions, Atmos. Chem. Phys., 13, 11221-11234, doi:10.5194/acp13-11221-2013, 2013.

Austin, J., Wilson, J., and Li, F.: Evolution of water vapor concentrations and stratospheric age of air in coupled chemistryclimate model simulations, J. Atmos. Sci., 64, 905-921, doi:10.1175/JAS3866.1, 2007.

Bates, D. R. and Nicolet, M.: Atmospheric hydrogen, Publ. Astron. Soc. Pac., 62, 106-110, 1950.

Bekki, S., Rap, A., Poulain, V., Dhomse, S., Marchand, M., Lefevre, F., Forster, P. M., Szopa, S., and Chipperfield, M. P.: Climate impact of stratospheric ozone recovery, Geophys. Res. Lett., 40, 2796-2800, doi:10.1002/grl.50358, 2013.

Brasseur, G. and Solomon, S.: Composition and Chemistry, in: Aeronomy of the Middle Atmosphere, 3rd Edn., Springer, Dordrecht, Netherlands, 265-422, 2005.

Brewer, A. W.: Evidence for a world circulation provided by the measurements of helium and water vapor distribution in the stratosphere, Q. J. Roy. Meteor. Soc., 75, 351-363, doi:10.1002/qj.49707532603, 1949.

Butchart, N. and Scaife, A.: Removal of chlorofluorocarbons by increased mass exchange between the stratosphere and troposphere in a changing climate, Nature, 410, 799-802, doi:10.1038/35071047, 2001.

Butchart, N., Cionni, I., Eyring, V., Shepherd, T. G., Waugh, D. W., Akiyoshi, H., Austin, J., Brühl, C., Chipperfield, M. P., Cordero, E., Dameris, M., Deckert, R., Dhomse, S., Frith, S. M., Garcia, R. R., Gettelman, A., Giorgetta, M. A., Kinnison, D. E., Li, F., Mancini, E., McLandress, C., Pawson, S., Pitari, G., Plummer, D. A., Rozanov, E., Sassi, F., Scinocca, J. F., Shibata, K., Steil, B., and Tian, W.: Chemistry-climate model simulations of twentyfirst century stratospheric climate and circulation changes, J. Climate, 23, 5349-5374, doi:10.1175/2010JCLI3404.1, 2010.

CCMI - Chemistry-Climate Model Initiative: available at: http: //www.sparc-climate.org/activities/ccm-initiative/, last access: 9 June 2016.

Davis, S. M., Rosenlof, K. H., Hassler, B., Hurst, D. F., Read, W. G., Vömel, H., Selkirk, H., Fujiwara, M., and Damadeo, R.: The Stratospheric Water and Ozone Satellite Homogenized (SWOOSH) database: a long-term database for climate studies, Earth Syst. Sci. Data, 8, 461-490, doi:10.5194/essd-8-461-2016, 2016.

Dessler, A. E., Schoeberl, M. R., Wang, T., Davis, S. M., and Rosenlof K. H.: Stratospheric water vapor feedback, P. Natl. Acad. Sci. USA, 110, 18087-18091, doi:10.1073/pnas.1310344110, 2013.

Dessler, A. E., Ye, H., Wang, T., Schoeberl, M. R., Oman, L. D., Douglass, A. R., Butler, A. H., Rosenlof, K. H., Davis, S. M., and Portmann, R. W.: Transport of ice into the stratosphere and the humidification of the stratosphere over the 21 st century, Geophys. Res. Lett., 43, 2323-2329, doi:10.1002/2016GL067991, 2016.

Dhomse, S., Weber, M., and Burrows, J.: The relationship between tropospheric wave forcing and tropical lower stratospheric water vapor, Atmos. Chem. Phys., 8, 471-480, doi:10.5194/acp-8-4712008, 2008.

Egorova, T. A., Rozanov, E. V., Zubov, V. A., and Karol, I. L.: Model for investigating ozone trends (MEZON), Izv. Atmos. Ocean. Phys., 39, 277-292, 2003.

ETH-PMOD: Swiss Federal Institute of Technology Zurich and the Physical-Meteorology Observatory Davos, Data, Part of the Chemistry-Climate Model Initiative (CCMI-1) Project Database, NCAS British Atmospheric Data Centre, available at: http:// catalogue.ceda.ac.uk/uuid/1005d2c25d14483aa66a5f4a7f50fcf0 (20 October 2016), 2015.

Eyring, V., Butchart, N., Waugh, D. W., Akiyoshi, H., Austin, J., Bekki, S., Bodeker, G. E., Boville, B. A., Brühl, C., Chipperfield, M. P., Cordero, E., Dameris, M., Deushi, M., Fioletov, V. E., Frith, S. M., Garcia, R. R., Gettelman, A., Giorgetta, M. A., Grewe, V., Jourdain, L., Kinnison, D. E., Mancini, E., Manzini, E., Marchand, M., Marsh, D. R., Nagashima, T., Newman, P. A., Nielsen, J. E., Pawson, S., Pitari, G., Plummer, D. A., Rozanov, E., Schraner, M., Shepherd, T. G., Shibata, K., Stolarski, R. S., Struthers, H., Tian, W., and Yoshiki, M.: Assessment of temperature, trace species, and ozone in chemistry-climate model simulations of the recent past, J. Geophys. Res., 111, D22308, doi:10.1029/2006JD007327, 2006.

Eyring, V., Lamarque, J.-F., Hess, P., Arfeuille, F., Bowman, K., Chipperfield, M. P., Duncan, B., Fiore, A., Gettelman, A., Giorgetta, M. A., Granier, C., Hegglin, M., Kinnison, D., Kunze, M., Langematz, U., Luo, B., Martin, R., Matthes, K., Newman, P. A., Peter, T., Robock, A., Ryerson, T., Saiz-Lopez, A., Salawitch, R., Schultz, M., Shepherd, T. G., Shindell, D., Staehelin, J., Tegtmeier, S., Thomason, L., Tilmes, S., Vernier, J.-P., Waugh, D. W., and Young, P. J.: Overview of IGAC/SPARC Chemistry-Climate Model Initiative (CCMI) Community Simulations in Support of Upcoming Ozone and Climate Assessments, SPARC Newsletter no. 40, ISSN 1245-4680, 48-66, 2013.

Fueglistaler, S., Bonazzola, M., Haynes, P. H., and Peter, T.: Stratospheric water vapor predicted from the Lagrangian temperature history of air entering the stratosphere in the tropics, J. Geophys. Res., 110, D08107, doi:10.1029/2004JD005516, 2005.

Garcia, R. R., Marsh, D. R., Kinnison, D. E., Boville, B. A., and Sassi, F.: Simulation of secular trends in the middle atmosphere, 1950-2003, J. Geophys. Res., 112, D09301, doi:10.1029/2006JD007485, 2007.

Gettelman, A., Hegglin, M. I., Son, S.-W., Kim, J., Fujiwara, M., Birner, T., Kremser, S., Rex, M., Añel, J. A., Akiyoshi, H., Austin, J., Bekki, S., Braesike, P., Brühl, C., Butchart, N., Chipperfield, M., Dameris, M., Dhomse, S., Garny, H., Hardiman, S. C., Jöckel, P., Kinnison, D. E., Lamarque, J. F., Mancini, E., Marchand, M., Michou, M., Morgenstern, O., Pawson, S., Pitari, G., Plummer, D., Pyle, J. A., Rozanov, E., Scinocca, J., Shepherd, T. G., Shibata, K., Smale, D., Teyssèdre, H., and Tian, W.: Multimodel assessment of the upper troposphere and lower stratosphere: Tropics and global trends, J. Geophys. Res., 115, D00M08, doi:10.1029/2009JD013638, 2010.

Grooß, J.-U. and Russell III, J. M.: Technical note: A stratospheric climatology for $\mathrm{O}_{3}, \mathrm{H}_{2} \mathrm{O}, \mathrm{CH}_{4}, \mathrm{NO}_{x}, \mathrm{HCl}$ and $\mathrm{HF}$ derived from HALOE measurements, Atmos. Chem. Phys., 5, 2797-2807, doi:10.5194/acp-5-2797-2005, 2005.

Hartmann, D. L., Klein Tank, A. M. G., and Rusticucci, M.: Observations: Atmosphere and Surface, chap. 2 in: Climate Change 
2013: The Physical Science Basis. Contribution of Working Group I to the Fifth Assessment Report of the Intergovernmental Panel on Climate Change, Cambridge University Press, Cambridge, U. K. and New York, NY, USA, 2013.

Hegglin, M. I., Plumer, D. A., Shepherd, T. G., Scinocca, J. F., Anderson, J., Froidevaux, L., Funke, B., Hurst, D., Rozanov, A., Urban, J., von Clarmann, T., Walker, K. A., Wang, H. J., Tegtmeier, S., and Weigel, K.: Vertical structure of stratospheric water vapour trends derived from merged satellite data, Nat. Geosci., 7, 768-776, doi:10.1038/NGEO2236, 2014.

Holton, J. R. and Gettelman, A.: Horizontal transport and the dehydration of the stratosphere, Geophys. Res. Lett., 28, 2799-2802, doi:10.1029/2001GL013148, 2001.

Hurst, D. F., Oltmans, S. J., Völmel, H., Rosenlof, K. H., Davis, S. M., Ray, E. A., Hall, E. G., and Jordan, A. F.: Stratospheric water vapor trends over Boulder, Colorado: Analysis of the 30 year Boulder record, J. Geophys. Res., 116, D02306, doi:10.1029/2010JD015065, 2011.

Joshi, M. M., Charlton, A. J., and Scaife, A. A.: On the influence of stratospheric water vapor changes on the tropospheric circulation, Geophys. Res. Lett., 33, L09806, doi:10.1029/2006GL025983, 2006.

Kirk-Davidoff, D. B., Hintsa, E. J., Anderson, J. G., and Keith, D. W.: The effect of climate change on ozone depletion through changes in stratospheric water vapour, Nature, 402, 399-401, doi:10.1038/46521, 1999.

Laeng, A., Plieninger, J., von Clarmann, T., Grabowski, U., Stiller, G., Eckert, E., Glatthor, N., Haenel, F., Kellmann, S., Kiefer, M., Linden, A., Lossow, S., Deaver, L., Engel, A., Hervig, M., Levin, I., McHugh, M., Noël, S., Toon, G., and Walker, K.: Validation of MIPAS IMK/IAA methane profiles, Atmos. Meas. Tech., 8, 5251-5261, doi:10.5194/amt-8-5251-2015, 2015.

Lamarque, J.-F., Bond, T. C., Eyring, V., Granier, C., Heil, A., Klimont, Z., Lee, D., Liousse, C., Mieville, A., Owen, B., Schultz, M. G., Shindell, D., Smith, S. J., Stehfest, E., Van Aardenne, J., Cooper, O. R., Kainuma, M., Mahowald, N., McConnell, J. R., Naik, V., Riahi, K., and van Vuuren, D. P.: Historical (1850-2000) gridded anthropogenic and biomass burning emissions of reactive gases and aerosols: methodology and application, Atmos. Chem. Phys., 10, 7017-7039, doi:10.5194/acp10-7017-2010, 2010.

Le Texier, H., Solomon, S., and Garcia, R. R.: The role of molecular hydrogen and methane oxidation in the water vapour budget of the stratosphere, Q. J. Roy. Meteor. Soc., 114, 281-295, doi:10.1002/qj.49711448002, 1988.

Luo, B. P.: Stratospheric aerosol data for use in CCMI models, available at: ftp://iacftp.ethz.ch/pub_read/luo/ccmi/ (last access: 5 May 2016), 2013.

MacKenzie, I. A. and Harwood, R. S.: Middle-atmospheric response to a future increase in humidity arising from increased methane abundance, J. Geophys. Res., 109, D02107, doi:10.1029/2003JD003590, 2004.

Masui, T., Matsumoto, K., Hijioka, Y., Kinoshita, T., Nozawa, T., Ishiwatari, S., Kato, E., Shukla, P. R., Yamagata, Y., and Kainuma, M.: An emission pathway for stabilization at $6 \mathrm{Wm}^{-2}$ radiative forcing, Climatic Change, 109, 59-76, doi:10.1007/s10584-011-0150-5, 2011.

Maycock, A. C., Joshi, M. M., Shine, K. P., and Scaife, A. A.: The circulation response to idealized changes in stratospheric water vapor, J. Climate, 26, 545-561, doi:10.1175/JCLI-D-1200155.1, 2013.

Meehl, G. A., Washington, W. M., Arblaster, J. M., Hu, A., Teng, H., Kay, J. E., Gettelman, A., Lawrence, D. M., Sanderson, B. M., and Strand, W. G.: Climate change projections in CESM1(CAM5) compared to CCSM4, J. Climate, 26, 62876308, doi:10.1175/JCLI-D-12-00572.1, 2013.

Montzka, S. A., Dlugokencky, E. J., and Butler, J. H.: Non$\mathrm{CO}_{2}$ greenhouse gases and climate change, Nature, 476, 43-50, doi:10.1038/nature10322, 2011.

Nakicenovic, N. and Swart, R. (Eds.): IPCC Special Report on Emissions Scenarios, Cambridge Univ. Press, Cambridge, UK, 2000.

Oltmans, S. J. and Hofmann, D. J.: Increase in lower-stratospheric water vapour at a mid-latitude Northern Hemisphere site from 1981 to 1994 , Nature, 374, 146-149, doi:10.1038/374146a0, 1995.

Oman, L., Waugh, D. W., Pawson, S., Stolarski, R. S., and Nielsen, J. E.: Understanding the changes of stratospheric water vapor in coupled chemistry-climate model simulations, J. Atmos. Sci., 65, 3278-3291, doi:10.1175/2008JAS2696.1, 2008.

Pawson, S. and Steinbrecht, W.: Update on global ozone: Past, present, and future, in Scientific Assessment of Ozone Depletion: 2014, WMO Global Ozone Res. Monit. Proj. Rep.,World Meteorol. Organization, Geneva, Switzerland, 55, chap. 2, 2014.

Plieninger, J., Laeng, A., Lossow, S., von Clarmann, T., Stiller, G. P., Kellmann, S., Linden, A., Kiefer, M., Walker, K. A., Noël, S., Hervig, M. E., McHugh, M., Lambert, A., Urban, J., Elkins, J. W., and Murtagh, D.: Validation of revised methane and nitrous oxide profiles from MIPAS-ENVISAT, Atmos. Meas. Tech., 9, 765-779, doi:10.5194/amt-9-765-2016, 2016.

Randel, W. J., Wu, F., Russell III, J. M., Roche, A., and Waters, J. W.: Seasonal cycles and QBO variations in stratospheric $\mathrm{CH}_{4}$ and $\mathrm{H}_{2} \mathrm{O}$ observed in UARS HALOE data, J. Atmos. Sci., 55, 163-185, doi:10.1175/15200469(1998)055<0163:SCAQVI>2.0.CO;2, 1998.

Randel, W. J., Wu, F., Oltmans, S. J., Rosenlof, K., and Nedoluha, G. E.: Interannual changes of stratospheric water vapor and correlations with tropical tropopause temperatures, J. Atmos. Sci., 61, 2133-2148, doi:10.1175/15200469(2004)061<2133:ICOSWV>2.0.CO;2, 2004.

Randel, W. J., Wu, F., Vömel, H., Nedoluha, G. E., and Forster, P.: Decreases in stratospheric water vapor after 2001: Links to changes in the tropical tropopause and the Brewer-Dobson circulation, J. Geophys. Res., 111, D12312, doi:10.1029/2005JD006744, 2006.

Revell, L. E., Bodeker, G. E., Huck, P. E., Williamson, B. E., and Rozanov, E.: The sensitivity of stratospheric ozone changes through the 21 st century to $\mathrm{N}_{2} \mathrm{O}$ and $\mathrm{CH}_{4}$, Atmos. Chem. Phys., 12, 11309-11317, doi:10.5194/acp-12-11309-2012, 2012.

Revell, L. E., Tummon, F., Stenke, A., Sukhodolov, T., Coulon, A., Rozanov, E., Garny, H., Grewe, V., and Peter, T.: Drivers of the tropospheric ozone budget throughout the 21 st century under the medium-high climate scenario RCP 6.0, Atmos. Chem. Phys., 15, 5887-5902, doi:10.5194/acp-15-5887-2015, 2015.

Riahi, K., Rao, S., Krey, V., Cho, C., Chirkov, V., Fischer, G., Kindermann, G., Nakicenovic, N., and Rafaj, P.: RCP 8.5 - A scenario of comparatively high greenhouse gas emissions, Climatic Change, 109, 33-57, doi:10.1007/s10584-011-0149-y, 2011. 
Roeckner, E., Bäuml, G., Bonaventura, L., Brokopf, R., Esch, M., Giorgetta, M., Hagemann, S., Kirchner, I., Kornblueh, L., Manzini, E., Rhodin, A., Schlese, U., Schulzweida, U., and Tompkins, A.: The atmospheric general circulation model ECHAM 5. Part I: Model description, Max-PlanckInstitut für Meteorologie, Hamburg, Report No. 349, available at: http://www.mpimet.mpg.de/fileadmin/publikationen/Reports/ max_scirep_349.pdf (last access: 20 October 2016), 2003.

Rohs, S., Schiller, C., Riese, M., Engel, A., Schmidt, U., Wetter, T., Levin, I., Nakazawa, T., and Aoki, S.: Long-term changes of methane and hydrogen in the stratosphere in the period 1978-2003 and their impact on the abundance of stratospheric water vapor, J. Geophys. Res., 111, D14315, doi:10.1029/2005JD006877, 2006.

Rosenlof, K. H.: Transport changes inferred from HALOE water and methane measurements, J. Meteorol. Soc. Jpn., 80, 831-848, doi:10.2151/jmsj.80.831, 2002.

Sander, S. P., Abbatt, J., Barker, J. R., Burkholder, J. B., Friedl, R. R., Golden, D. M., Huie, R. E., Kolb, C. E., Kurylo, M. J., Moortgat, G. K., Orkin, V. L., and Wine, P. H.: Chemical Kinetics and Photochemical Data for Use in Atmospheric Studies, Evaluation No. 17, JPL Publication 10-6, Jet Propulsion Laboratory, Pasadena, available at: http://jpldataeval.jpl.nasa.gov (last access: 20 October 2016), 2011.

Scaife, A. A., Butchart, N., Jackson, D. R., and Swinbank, R.: Can changes in ENSO activity help to explain increasing stratospheric water vapor?, Geophys. Res. Lett., 30, 1880, doi:10.1029/2003GL017591, 2003.

Schieferdecker, T., Lossow, S., Stiller, G. P., and von Clarmann, T.: Is there a solar signal in lower stratospheric water vapour?, Atmos. Chem. Phys., 15, 9851-9863, doi:10.5194/acp-15-98512015, 2015.

Schraner, M., Rozanov, E., Schnadt Poberaj, C., Kenzelmann, P., Fischer, A. M., Zubov, V., Luo, B. P., Hoyle, C. R., Egorova, T., Fueglistaler, S., Brönnimann, S., Schmutz, W., and Peter, T.: Technical Note: Chemistry-climate model SOCOL: version 2.0 with improved transport and chemistry/microphysics schemes, Atmos. Chem. Phys., 8, 5957-5974, doi:10.5194/acp-8-59572008, 2008.

Seidel, D. J., Ross, R. J., Angell, J. K., G. C. Reid, G. C.: Climatological characteristics of the tropopause as revealed by radiosondes, J. Geophys. Res., 106, 7857-7878, doi:10.1029/2000JD900837, 2001.

Solomon, S., Rosenlof, K. H., Portmann, R. W., Daniel, J. S., Davis, S. M., Sanford, T. J., and Plattner, G.-K.: Contributions of stratospheric water vapor to decadal changes in the rate of global warming, Science, 327, 1219-1223, doi:10.1126/science.1182488, 2010.
SPARC CCMVal-2, Eyring, V., Shepherd, T. G., and Waugh, D. W. (Eds.): SPARC report on the evaluation of chemistry-climate models, SPARC Rep. 5, WCRP-132, WMO/TD 1526, World Clim. Res. Programme, Geneva, Switzerland, 2010.

Stenke, A. and Grewe, V.: Simulation of stratospheric water vapor trends: impact on stratospheric ozone chemistry, Atmos. Chem. Phys., 5, 1257-1272, doi:10.5194/acp-5-1257-2005, 2005.

Stenke, A., Schraner, M., Rozanov, E., Egorova, T., Luo, B., and Peter, T.: The SOCOL version 3.0 chemistry-climate model: description, evaluation, and implications from an advanced transport algorithm, Geosci. Model Dev., 6, 1407-1427, doi:10.5194/gmd-6-1407-2013, 2013.

Sukhodolov, T., Rozanov, E., Shapiro, A. I., Anet, J., Cagnazzo, C., Peter, T., and Schmutz, W.: Evaluation of the ECHAM family radiation codes performance in the representation of the solar signal, Geosci. Model Dev., 7, 2859-2866, doi:10.5194/gmd-72859-2014, 201

Thomson, A. M., Calvin, K. V., Smith, S. J., Page Kyle, G., Volke, A., Patel, P., Delgado-Arias, S., Bond-Lamberty, B., Wise, M. A., Clarke, L. E., and Edmonds, J. A.: RCP 4.5: a pathway for stabilization of radiative forcing by 2100 , Climatic Change, 109 , 77-94, doi:10.1007/s10584-011-0151-4, 2011.

Tian, W. and Chipperfield, M.: Stratospheric water vapor trends in a coupled chemistry-climate model, Geophys. Res. Lett., 33, L06819, doi:10.1029/2005GL024675, 2006.

van Vuuren, D. P., Edmonds, J., Kainuma, M., Riahi, K., Thomson, A., Hibbard, K., Hurtt, C. G., Kram, T., Krey, V., Lamarque, J.F., Masui, T., Meinshausen, M., Nakicenovic, N., Smith, S. J., and Rose, S. K.: The representative concentration pathways: an overview, Climatic Change, 109, 5-31, doi:10.1007/s10584-0110148-z, 2011a.

van Vuuren, D. P., Stehfest, E., den Elzen, M. G. J., Kram, T., van Vliet, J., Deetman, S., Isaac, M., Klein Goldewijk, K., Hof, A., Mendoza Beltran, A., Oostenrijk, R., and van Ruijven, B: RCP2.6: exploring the possibility to keep global mean temperature increase below $2^{\circ} \mathrm{C}$, Climatic Change, 109, 95-116, doi:10.1007/s10584-011-0152-3, 2011b.

World Meteorological Organization: Scientific Assessment of Ozone Depletion: 2010, WMO Global Ozone Research and Monitoring Project - Report No. 52, Geneva, Switzerland, 2011. 